http://dx.doi.org/10.1590/0370-44672018720021

\author{
Lucas Gibram Leite e Silva ${ }^{1,2,5}$ \\ https://orcid.org/0000-0002-1835-7089 \\ Wagner Pires Dias ${ }^{3,6}$ \\ Cláudio Batista Vieira ${ }^{1,4,7}$ \\ http://orcid.org/0000-0003-2556-6310 \\ Paulo Santos Assis ${ }^{1,4,8}$
}

'Universidade Federal de Ouro Preto - UFOP, Universidade Estadual de Minas Gerais - UEMG, Rede Temática em Engenharia de Materiais REDEMAT, Ouro Preto - Minas Gerais - Brasil.

${ }^{2}$ ForGreen Energia Renovável,

Belo Horizonte - Minas Gerais - Brasil.

${ }^{3}$ Vale Manganês S.A.

Barbacena - Minas Gerais - Brasil.

${ }^{4}$ Universidade Federal de Ouro Preto - UFOP, Escola de Minas - Departamento de Engenharia Metalúrgica e de Materiais, Ouro Preto - Minas Gerais - Brasil.

E-mails: ${ }^{5}$ gibramlucas@gmail.com,

6wwagner.dias@vale.com, ${ }^{7}$ geometalurgia@yahoo.com.br, 8assis@ufop.edu.br

\section{Introduction}

The ferroalloy industry has a huge electric energy dependency. In Brazil, till 1950 , those who wanted to produce ferroalloy had to provide their own energy supply. Nowadays, despite having enough energy available, the high prices and constant increasing of its tariff, causes some productions to become unviable (Garcia, 2007). The energy availability, quality and price directly impact the competitiveness of the sector. Electric energy represents

\title{
Solar photovoltaic energy applied to ferroalloy industry \\ Abstract
}

The Brazilian ferroalloy industry faces a highly competitive scenario in the foreign market. Among the key factors to determine the price of its products, electric energy stands out as one of the main inputs. So, the possibility of energy being unavailable or having high prices causes a direct impact in the ferroalloy chain. On the other hand, the renewable energy market, especially the solar photovoltaic (SPV) energy shows extensive growth due to technological advances and recent regulation. Connecting both contexts, this study investigates a way to apply the great moment of the SPV energy sector to the ferroalloys industry. Firstly, the ferroalloy sector data was searched in order to develop a model of ferroalloy production by using the average data of production and electric energy consumption, called model-ferroalloy. So an SPV power plant was estimated to supply its electric energy demand. It was considered in four different scenarios according to current law and its economic viability verified. From these studies, the viability of implementing solar photovoltaic energy to ferroalloys industry was determined. The levelized cost of energy (LCOE) comparative shows that SPV energy has a lower price than conventional sources, no matter if it is in the free or regulated energy market. Furthermore, the necessary investment, according to the results found, has good attractiveness in the financial market point of view.

Keywords: solar photovoltaic energy, ferroalloy industry, viability.

$35 \%$ of the production costs, in average, but it can increase up to $40 \%$ (Kruger, 2009). Great energy consumers in Brazil, as ferroalloys, can choose between two energy contraction environments. It could be by local concessionary with regulated tariffs or by a free market of energy with bilateral negotiation. (Abradee, 2018)

In manganese ferroalloy production around the world, for example, the most used way is the electric reduction furnace
(Faria et al., 2014). Souza (2016) shows that manganese ore is a strategic mineral to Brazil due to its widespread use in ferroalloys production. It has great prominence in Brazil, owing to the large existing reserves and concentrated production.

In Brazil, the main source of energy is hydro, representing up to $60 \%$. However, renewable sources are increasing their representativeness. This fact can be observed in Table 1. (Tolmasquim, 2016).

Table 1 - Brazilian electric generation power capacity.

\begin{tabular}{|c|c|c|c|c|c|c|c|}
\hline & 2011 & 2012 & 2013 & 2014 & 2015 & Deviation \% (2015/2014) & Part. \% (2015) \\
\hline TOTAL & 117,136 & 120,974 & 126,743 & 133,913 & 140,271 & $4.5 \%$ & 100.0 \\
\hline Hydroelectric Plant & 78,347 & 79,956 & 81,132 & 84,095 & 86,002 & $2.2 \%$ & $61.3 \%$ \\
\hline Thermoelectric Plant & 31,243 & 32,778 & 36.528 & 37,827 & 39,393 & $4.0 \%$ & $28.1 \%$ \\
\hline Small Hydropower & 3,896 & 4,101 & 4,620 & 4,790 & 4,840 & $1.0 \%$ & $3.5 \%$ \\
\hline Central Hydrogeneration & 216 & 236 & 266 & 308 & 395 & $22.0 \%$ & $0.3 \%$ \\
\hline Nuclear Power Plant & 2,007 & 2,007 & 1,990 & 1,990 & 1,990 & $0.0 \%$ & $1.4 \%$ \\
\hline Wind Power Plant & 1,426 & 1,894 & 2,202 & 4,888 & 7,630 & $35.9 \%$ & $5.4 \%$ \\
\hline Solar PV Power Plant & 1 & 2 & 5 & 15 & 21 & $28.6 \%$ & $0.0 \%$ \\
\hline
\end{tabular}

Tolmasquim, 2016 
The reasons for this rate of growth are related to the dropping costs of solar and wind energy in opposition to fossil fuels. This change becomes strongest by the social and environmental engagement policies (Akella et al., 2009), In comparison to the energy matrix, Solar Photovoltaic (SPV) is a shiny source. The regulation of distributed generation by Normative Resolution (REN) 482/2012 and REN 687/2015 was one of the most important aspects to increase this energy source. This model allows that the surplus generated energy can be injected at the grid and accumulated as energy credit to be used till 60 months. That means the possibility to supply the

\section{Methodology}

The first step was to research the actual status of the ferroalloy industry related to the production and energy consumption per produced ton. Then, a Standard- Ferroalloy (SFA) was defined by using the average value of produced alloy and energy consumption. This standard was created just to obtain a model

representative enough to the entire sector, despite of the natural differences between each ferroalloy.

Calculated was the solar power plant needed to supply the SFA energy consumption. This calculation was made based on the photovoltaic production map in terms of $\mathrm{kWh} / \mathrm{kWp}$, by the Brazilian

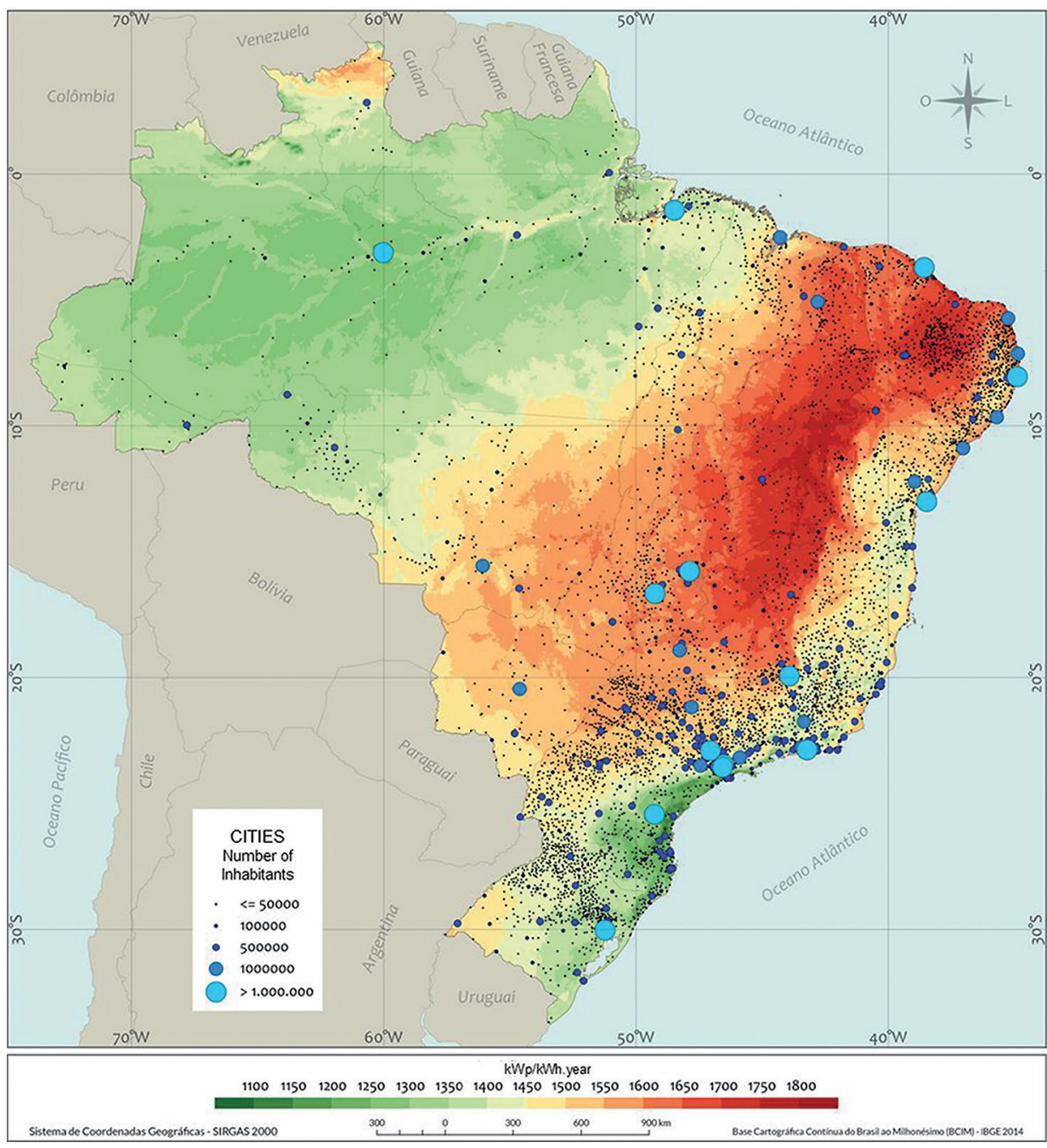

inverter to change the direct to alternated current, cable and other devices. In some cases, accumulative systems could be used for off-grid connections, but it is too expensive yet. In the on-grid model, the energy distribution net does the rule of batteries by cumulating $\mathrm{kWh}$ credits in months when the SPV energy generation exceeds consumption and compensating the consumption when there is no or not enough sun to supply whole energy demand. So, this article aims to evaluate the investment, payback and energy cost in comparison to conventional sources. It could open a door to dissemination of SPV energy to the great consumers, especially the ferroalloy industry.

Solar Energy Atlas as shown in Figure 1 (Pereira et al., 2017). This publication considered the average performance rate of $80 \%$ for certified equipment correctly projected and with good installation. The conversion constant chosen was $1,690 \mathrm{kWh} / \mathrm{kWp}$, the third quartile of the scale.
Figure 1 SPV energy generation map - kWh/kWp.year (Pereira et al., 2017). 
The investment required to build this solar photovoltaic power plant was found by market research. A questionnaire was sent to some sellers of SPV materials such as photovoltaic panels and inverter and engineering companies. Furthermore, four possible scenarios were simulated to evaluate this idea, which are:

a. Limited to $5.0 \mathrm{MW}$ in the regulated market because this is the legal limit of the distributed generation by REN 687/2015;

b. Supplying $100 \%$ of consumption by building as many $5.0 \mathrm{MW}$-solarpower-plants as necessary to deliver the average energy consumed and keep at the distributed generation model from REN 687;

\section{Results}

The characterization of the average ferroalloy production, here

Table 2

Energy demand by standard-ferroalloy.

According to the market research of costs and calculus of each proposed

Table 3

Material and services costs. c. As energy auto-producer for free market of energy. In this way, there is no credit of energy delivered to the net and further compensation, but all the solar energy generated during day must be consumed. So, just $20 \%$ of the energy need was considered;

d. Same as above, but considering that it is possible to accumulate credit for use when the day is not sunny, as REN 687.

As comparative value of electric energy price possibly paid by ferroalloy industry, it was used the cost from energy company of the state of Minas Gerais (CEMIG) at R\$ 0,2518/kWh (Aneel, 2017). At the free market of energy, as the price and conditions are negotiated freely by the purchaser and the energy seller in each contract, it was used the price of energy informed for a real ferroalloy company that is $\mathrm{R} \$ 0,21618 / \mathrm{kWh}$.

Finally, to evaluate the financial availability of this enterprise it was used the concept of the Levelized Cost of Energy - LCOE (IRENA, 2012). This tool is frequently used to compare sources of energy by figuring out the total cost of building, operation and maintenance versus the total of electric energy produced $(\mathrm{kWh})$ in the lifetime, resulting a value in terms of $\mathrm{R} \$ / \mathrm{kWh}$. Also was done the investment analysis by using the figures of internal rate of return (IRR), net present value (NPV) and payback (Rossarola, 2016; Nakabayashi, 2014).

called standard-ferroalloy, is shown at table 2 below:

\begin{tabular}{c|c|c|c|c}
\multicolumn{2}{c|}{ Item } & Value & Unity & Source \\
\hline A & $\begin{array}{c}\text { National Ferroalloy Production } \\
(2014)\end{array}$ & $1,281,331.72$ & $\mathrm{t} /$ year & MME, 2015 \\
\hline B & $\begin{array}{c}\text { Specific Energy Consumption of } \\
\text { Ferroalloys }\end{array}$ & $7,821.00$ & $\mathrm{kWh} / \mathrm{t}$ & Leite, 2010 \\
\hline C & $\begin{array}{c}\text { Number of ferroalloys production } \\
\text { plants }\end{array}$ & 30.00 & units & Kruger, 2009 \\
\hline $\mathrm{D}$ & $\begin{array}{c}\text { Electric energy consumption } \\
\text { recorded }\end{array}$ & $16,642,530,000.00$ & $\mathrm{kWh} /$ year & $\mathrm{MME}, 2015$ \\
\hline $\mathrm{E}$ & $\begin{array}{c}\text { Electric energy consumption } \\
\text { calculated }\end{array}$ & $10,021,295,399.50$ & $\mathrm{kWh} /$ year & $(\mathrm{A} \times \mathrm{B})$ \\
\hline $\mathrm{F}$ & $\begin{array}{c}\text { Consumption of Electric energy } \\
\text { estimated }\end{array}$ & $444,397,089.99$ & $\mathrm{kWh} /$ year & $($ Average(D;E)/C) \\
\hline $\mathrm{G}$ & $\begin{array}{c}\text { Solar photovoltaic energy } \\
\text { generation factor }\end{array}$ & $1,690.00$ & $\mathrm{kWh} / \mathrm{kWp}$ & Pereira et al., 2017 \\
\hline $\mathrm{H}$ & Installed power plant of SPV energy & $262,956.86$ & $\mathrm{kWp}$ & $(\mathrm{F} / \mathrm{G})$ \\
\hline $\mathrm{I}$ & \begin{tabular}{c} 
Number of SPV Panels \\
\hline
\end{tabular} & 796,839 & Panels & $(\mathrm{H} / 0.330 \mathrm{~W})$ \\
\hline
\end{tabular}

scenario, the required investment for this project is shown at table 3 .

\begin{tabular}{c|c|cc|c}
$\begin{array}{c}\text { Installed Power } \\
(\mathbf{M W})\end{array}$ & $\begin{array}{c}\text { Equipment costs } \\
(\mathbf{R} \$ \mathbf{)}\end{array}$ & $\begin{array}{c}\text { Services costs } \\
\mathbf{( R \$ )}\end{array}$ & $\begin{array}{c}\text { Final Cost } \\
{[+\mathbf{2 0 \%} \text { for safety] }} \\
\mathbf{( R \$ )}\end{array}$ \\
\hline 5 & $\mathrm{R} \$ 12,631,215.18$ & $\mathrm{R} \$ 5,100,000.00$ & $\mathrm{R} \$ 21,277,458.22$ \\
\hline 52.59 & $\mathrm{R} \$ 113,683,565.21$ & $\mathrm{R} \$ 53,643,199.03$ & $\mathrm{R} \$ 200,792,117.09$ \\
\hline 262.96 & $\mathrm{R} \$ 511,962,074.65$ & $\mathrm{R} \$ 268,215,995.14$ & $\mathrm{R} \$ 936,213,683.75$ \\
\hline
\end{tabular}

As availability study result it was found the following values for LCOE, IRR, NPV and payback, at table 4 and 5.

Table 4

Calculated LCOE comparative.

\begin{tabular}{c|c} 
Situation & LCOE 20 years (R\$/kWh) \\
\hline Conventional Energy (regulated market) & 0.86 \\
\hline Free market of energy & 0.40 \\
\hline Solar Photovoltaic Energy & 0.255 \\
\hline
\end{tabular}




\begin{tabular}{c|c|c|c} 
SCENARIO & IRR & NPV (R\$) & PAYBACK (years) \\
\hline$a$ & $11.05 \%$ & $\mathrm{R} \$ 46,602,122.23$ & 9.00 \\
\hline$b$ & $13.56 \%$ & $\mathrm{R} \$ 2,717,318,155.79$ & 8.00 \\
\hline$c$ & $9.45 \%$ & $\mathrm{R} \$ 366,123,553.83$ & 10.00 \\
\hline$d$ & $10.75 \%$ & $\mathrm{R} \$ 1,971,636,140.21$ & 9.00 \\
\hline
\end{tabular}

\section{Discussion}

The characterization of a standard unit of ferroalloy production and energy consumption had the goal to show a profile representative of all of the sector. By using this representative model, the simulation of SPV energy use provides results which could be an import baseline to investment analysis in ferroalloy industry.

The prices of materials and services, including engineering, projecting and building, were defined by the market research sent to SPV companies. So, a real situation can reveal a different condition. In addition to the data found in the market research, a security margin of $20 \%$ was added to cover any unlisted costs and deviation from conformity.

\section{Conclusion}

According to the original purpose, this article showed the situation and general results for the implementation of clean and renewable energy to the ferroalloy industry. It is concluded that in terms of price of energy (LCOE), it is better to self-generate by SPV energy than to keep on with the regulated market and also better than the free market of energy.

\section{Acknowledgments}

The authors cordially thank REDEMAT/UFOP, ForGreen Energia
This addition may be unnecessary if all conditions were favorable, making the financial results even better.

From the financial point of view, the LCOE calculation showed a very positive result to SPV energy in parallel with the conventional source of energy. The cost in R $\$ / \mathrm{kWh}$ of SPV energy was almost 30\% lower than the free market of energy and up to $60 \%$ lower than the regulated energy market. So, in long term analysis, it is a good investment. The whole amount of SPV energy consumed will cost less than others sources.

The economic indicators of investment showed values of IRR above $10 \%$, which indicate that there is viability. Only the scenario $c$ presented inferior
Both situations provide benefits to the energy consumers, with lower LCOE and viable investment. Reducing an input that represents up to $40 \%$ of the production cost, it is possible to reduce the final selling price, increasing the competitiveness of its products worldwide. Consequently, more income for the industrial sector means more invest-
Renovável and other companies that kindly collaborated with this research.
Table 5

Study of financial availability results. then $10 \%(9.45 \%)$. Situation $a$ and $b$ has shown $a$ better result than $c$ and $d$ caused by the higher prices of regulated energy in comparison to the free market of energy. It is also possible to figure out the gain of scale in prices of products, comparing a with $b$ and $c$ with $d$. It clearly influences the economic result.

The economic figures as IRR, NPV and payback that were found will not be labeled as good, moderate or bad, because it is a particular judgment of each investor and entrepreneur. The rule of the authors was to find those data and give the firsts steps to the evaluation of the possibility to apply SPV energy in a great energy consumer class as ferroalloy. ments in production, demanding more employment and social development.

Other benefits are achievable and possibly accounted for financially, such as carbon credit, sustainability certification, cultural and social impact to all people and environment involved, which were not discussed here. Those can be the themes for future articles.

\section{References}

ABRADEE, Associação Brasileira de Distribuidores de Energia Elétrica. Disponível em <http:/www.abradee.com.br/setor-de-distribuicao/tarifas-de-energia/tarifas-de-energia\#_ftn1>. Acesso em: agosto de 2018.

AKELLA, A. K., SAINI, R. P., SHARMA, M. P. Social and environmental impactis of renewable energy systems. Renewable Energy, v. 34, n, 1, p. 390-396. 2009.

ANEEL. Resolução Homologatória no 2.248 de 23 de maio de 2017. Homologa o resultado do Reajuste Tarifário Anual de 2017, as Tarifas de Energia - TE e as Tarifas de Uso do Sistema de Distribuição - TUSD referentes à Cemig Distribuição S/A - Cemig-D, e dá outras providências. Disponível em < http://www2.aneel.gov. br/cedoc/reh20172248ti.pdf >. Acesso em: outubro de 2017.

CASTRO, M. A. L. Nota Técnica n 0056/2017-SRD/ANEEL: Atualização das projeções de consumidores residenciais e comerciais com microgeração solar fotovoltaicos no horizonte 2017-2024. Agência Nacional de Energia Elétrica - ANEEL, 2017. 26p. Disponível em < http://www.aneel.gov.br/documents/656827/15234696/ 
Nota+T\%C3\%A9cnica_0056_PROJE\%C3\%87\%C3\%95ES+GD+2017/38cad9 ae-71f6-8788-0429-d097409a0ba9 >. Acesso em: outubro de 2017.

FARIA, G. L., JANNOTTI, N., ARAUJO, F. G. S. Particle disintegration of an important Brazilian manganese lump ore. Rem:Rev. Esc. Minas, Ouro Preto, v. 67, n. 1, p. 55-60, Mar. 2014.

GARCIA, L. G. Análise das estratégias para competitividade de uma indústria: estudo do setor de ferroligas do Estado de Minas Gerais. Belo Horizonte : Centro de Gestão Empreendedora da FEAD, 2007. 105 p. (Dissertação de Mestrado em Administração).

IRENA. Renewable energy technologies: Cost analysis series. Volume 1: Power Sector, Issue 4/5, Solar Photovoltaics, 2012.

KRUGER, P. V. Relatório Técnico 60: Perfil de Ferroligas. Secretaria de Geologia, Mineração e Transformação Mineral - SGM, Ministério de Minas e Energia - MME, 2009. 112p. Disponível em <http://www.mme.gov.br/documents/1138775/1256652/P34_RT60_Perfil_de_Ferroligas.pdf/f4ea1c60-4b7e-4ef6-926d-2928fcf57751>. Acesso em: agosto de 2017.

LEITE, Á. A. F., BAJAY, S.V., GORLA, F. D. Oportunidades de eficiência energética para a indústria: relatório setorial: ferros-ligas. Brasília: CNI, 2010. 46 p. ISBN 978-85-7957-003-2.

MME. Anuário Estatístico: Setor Metalúrgico. Secretaria de Geologia, Mineração e Transformação Mineral; Ministério de Minas e Energia - MME - Brasília, 2015. Disponível em < http://www.mme.gov.br/documents/1138775/1732813/An nu\%C3\%A1rio+Estat $\%$ C3\%ADstico+do+Setor+Metal\%C3\%BArgico+2015. pdf/3cd2fe18-4daa-4e51-8899-53f0cba47573>. Acesso em: agosto de 2017.

NAKABAYASHI, R. K. Microgeração fotovoltaica no Brasil: condições atuais e perspectivas futuras. São Paulo: Programa de Pós-Graduação em Energia, Instituto de Energia e Ambiente, Universidade de São Paulo, 2014. 106 p. (Dissertação de Mestrado em Ciências).

PEREIRA, E. B. et al. Atlas brasileiro de energia solar. (2.ed.). São José dos Campos: Instituto Nacional De Pesquisas Espaciais - INPE, 2017. 88p. ISBN 978-85-17-00089-8.

ROSSAROLA, A. Análise econômico-financeira de investimento em energia solare externalidades: estudo de caso de uma empresa industrial em Santa Catarina. Florianópolis: Universidade Federal de Santa Catarina, 2016. 92 p. (Bacharelado em Ciências Econômicas - Monografia).

SOUZA, H. S. et al . Concentration of manganese tailings via reverse flotation in an acid médium. Rem:Rev. Esc. Minas, Ouro Preto, v. 69, n. 1, p. 85-90, Mar. 2016.

TOLMASQUIM, M. T. Energia renovável: hidráulica, biomassa, eólica, solar, oceânica. Rio de Janeiro: Empresa de Pesquisa Energética - EPE, 2016. 452 p. ISBN 978-85-60025-06-0.

Received: 20 February 2018 - Accepted: 30 November 2018. 